\title{
In vitro salt tolerance induced secondary metabolites production in Abrus precatorius $\mathrm{L}$.
}

\author{
K.P. Lafna Farshana', P. Deepa ${ }^{2 *}$ \\ ${ }^{1}$ Department of Botany, MES Kalladi College, Palakkad - 678583, Kerala, India, ${ }^{2}$ Department of Botany, Korambayil \\ Ahammed Haji Memorial Unity Women's College, Malappuram - 676122, Kerala, India
}

Received: August 05, 2020 Revised: May 09, 2021 Accepted: May 16, 2021 Published: June 03, 2021

\section{*Corresponding Author:}

P. Deepa

E-mail: deepapsaj@gmail.com

\section{ABSTRACT}

The white seeded Abrus precatorius $\mathrm{L}$. is an important herbaceous medicinal plant with broad range of therapeutic effects. In the present study, the internode selected as explant for in vitro salt tolerance analysis. For callus induction, MS media with different concentrations and combinations of BAP, Kinetin and IBA were used. Better callus fresh weight and dry weight observed on MS medium supplemented with BAP $0.5 \mathrm{mg} / \mathrm{L}$ and Kinetin $1 \mathrm{mg} / \mathrm{L}$. To detect the in vitro salt tolerance potential of callus, $\mathrm{NaCl}$ at different concentrations $(0,20,40,60,80$ and $100 \mathrm{mM})$ were supplemented on MS + BAP $0.5 \mathrm{mg} / \mathrm{L}+$ Kinetin $1 \mathrm{mg} / \mathrm{L}$ of which $40 \mathrm{mM} \mathrm{NaCl}$ induced better callus proliferation. The callus grown without $\mathrm{NaCl}$ stress showed the presence of eight phytochemical compounds in GC-MS analysis. While the $\mathrm{NaCl}$ stress tolerant callus exhibited the presence of seventeen phytochemical compounds. All these analyzed compounds are with antimicrobial/ anti-oxidant properties. The present work will be very much helpful to ameliorate the production of medicinally significant compounds in pharmaceutical industry.

KEYWORDS: Callus, plant growth regulators, salt tolerance, secondary metabolites, GC-MS analysis, retention time.

\section{INTRODUCTION}

The genus Abrus Adans. includes about 18 species which belongs to the family Leguminosae and native to Africa, Madagascar, India and Indo-China (Swanepoel and Kolberg, 2011). The generic name, Abrus is derived from the Greek word habro which means delicate, elegant, pretty or soft in reference to the leaflets (Lewis et al., 2015). Among the species, white seeded Abrus precatorius $\mathrm{L}$. is a garden ornamental plant characterized by climbing, twining or trailing vine with slender branches. It is commonly known as 'white kunni' in Malayalam and 'kunch' in Bengali. The plant is best known for its white seeds which are used as beads and in percussion instruments. The species contain various kinds of alkaloids such as glycerrhizin, precol, abrol, abrasion, abrin A and abrin B (Joshi and Joshi, 2000). Moreover, the presence of abrin indicates the toxicity of white seeds. In addition to the toxic effect, the plant parts have many medicinal properties due to the presence of different secondary metabolites that including antimicrobial, anti-inflammatory, immunomodulatory and antitumor activities (Roy et al., 2012).

Plants need balanced abiotic factors for optimum biomass productivity. Occasionally, the proper plant development is arrested by different abiotic stresses. Salinity is one of the abiotic stresses that negatively influences the plant growth and development. Nowadays, soil salinity is a major issue in much crop plant cultivation, especially in case of rice cultivation. It can be negatively influenced on growth, development and yield of rice plants. In medicinal plants, salt stress induces the production of a number of secondary metabolites which are medicinally important (Jaleel et al., 2008). Currently, this method of production of medicinal compounds has a significant role in the pharmaceutical industry. The tissue culture technique is a better opportunity to implement salt stress in in vitro cultured plants. This in vitro approach can be produced a lot of progenies from a single explant by direct or indirect organogenesis. The explant may be any tissue of the mother plant with desired characters including leaf, node, internode, seed, rhizome, apical meristem etc. Application of plant growth regulators like auxins and cytokinins in an optimum ratio causes the regeneration of in vitro plantlets directly from explants (Loberant and Altman, 2009). In contrast, somatic embryogenesis on callus tissue in turn results micropropagation of plantlets by the regeneration of embryos from somatic cells of the callus. The potential of a single plant cell to regenerate an entire plant is the totipotency which is the basic reason behind the micropropagation (Marton and Czako, 2011).

Copyright: () The authors. This article is open access and licensed under the terms of the Creative Commons Attribution License (http:// creativecommons.org/licenses/by/4.0/) which permits unrestricted, use, distribution and reproduction in any medium, or format for any purpose, even commercially provided the work is properly cited. Attribution - You must give appropriate credit, provide a link to the license, and indicate if changes were made. 
In vitro salt stress has been researched in many medicinal plants like Centella asiatica (L.) Urb., Catharanthus roseus (L.) G. Don, Trigonella foenum-graecum L., Carthamus tinctorius L. etc. (Jaleel et al., 2008; Gengmao et al., 2015; Sahari et al., 2016; Ibrahim et al., 2018). To adapt unfavorable stress conditions, the salt tolerant plants produce different secondary metabolites to serve cellular functions essential for physiological processes. Secondary metabolites have no role in the growth and development of the plants, but they required to survive in the environment (Yang et al., 2018). The in vitro produced metabolites can be separated using GC-MS (Gas Chromatography-Mass Spectrometry) analysis, a technology for secondary metabolite profiling in extracts of plant and non-plant species. Gas chromatography separates the components of the mixture and mass spectroscopy analyzes each of the components separately (Sermakkani and Thangapandian, 2012). These stress induced metabolites frequently show medicinal properties to suppress different microbial diseases (Patra and Mohanta, 2014). Due to the present relevance, the study was focused on in vitro salt tolerance and related metabolite production in white seeded A. precatorius.

\section{MATERIALS AND METHODS}

\section{Plant Material and Sterilization}

The shoots of A. precatorius collected from Botanical Garden of Korambayil Ahammed Haji Memorial Unity Women's College, Manjeri, Kerala, India and immediately transferred to sterile polythene bag and tightly tied. Using a sterile blade, the internodes of the plants were separated and used as explants for in vitro studies. The explants incubated in $0.1 \%$ Bavistine for 3 hours followed by $1 \%$ Teepol treatment for 1 hour. Then, the explants washed thoroughly with double distilled water to remove the sterilizing agents. For further sterilization process, the explants treated with $0.1 \%$ mercuric chloride $\left(\mathrm{HgCl}_{2}\right)$ for $3-5$ minutes that followed by washing with sterile double distilled water and $70 \%$ ethanol.

\section{Callogenesis}

The sterile explants inoculated on selected culture media supplemented with proper concentrations of plant growth regulators. The MS media supplemented with different plant growth regulators including MS + BAP $0.5 \mathrm{mg} / \mathrm{L}+\mathrm{IBA} 0.5 \mathrm{mg} / \mathrm{L}$, $\mathrm{MS}+\mathrm{BAP} 1 \mathrm{mg} / \mathrm{L}+\mathrm{IBA} 1 \mathrm{mg} / \mathrm{L}, \mathrm{MS}+\mathrm{BAP} 0.5 \mathrm{mg} / \mathrm{L}+\mathrm{IBA}$ $1 \mathrm{mg} / \mathrm{L}, \mathrm{MS}+\mathrm{BAP} 1 \mathrm{mg} / \mathrm{L}+\mathrm{IBA} 0.5 \mathrm{mg} / \mathrm{L}, \mathrm{MS}+\mathrm{BAP} 0.5 \mathrm{mg} /$ $\mathrm{L}+$ Kinetin $0.5 \mathrm{mg} / \mathrm{L}, \mathrm{MS}+\mathrm{BAP} 1 \mathrm{mg} / \mathrm{L}+$ Kinetin $1 \mathrm{mg} / \mathrm{L}, \mathrm{MS}$ + BAP $0.5 \mathrm{mg} / \mathrm{L}+$ Kinetin $1 \mathrm{mg} / \mathrm{L}$ and $\mathrm{MS}+$ BAP $1 \mathrm{mg} / \mathrm{L}+$ Kinetin $0.5 \mathrm{mg} / \mathrm{L}$, were used to induce callus from the internodes. The prepared media sterilized at $121{ }^{\circ} \mathrm{C}$ for 30 minutes in an autoclave at the pressure of $15 \mathrm{psi}$. The $\mathrm{pH}$ of the medium maintained to 5.8 for optimum growth. The cultures kept under controlled conditions of light intensity, temperature and photoperiod which maintained in the incubation room.

\section{In vitro Salinity Stress}

The different concentrations of $\mathrm{NaCl}(0,20,40,60,80$ and $100 \mathrm{mM}$ ) used to provide salt stress in in vitro culture. The best callus inducing and proliferating medium, MS + BAP $0.5 \mathrm{mg} / \mathrm{L}+$ Kinetin $1 \mathrm{mg} / \mathrm{L}$, with $\mathrm{pH}$ of 5.8 selected to supply the salinity stress. The cultures were maintained at $24 \pm 2$ ${ }^{\circ} \mathrm{C}$ with light intensity of $1500 \mu \mathrm{Em}^{-2} \mathrm{~S}^{-1}$ and photoperiod of 8 hours. The growth changes were observed and photographed weekly. The data analyzed statistically using single factor ANOVA.

\section{Secondary Metabolite Analysis}

The secondary metabolites in the hexane extract of the calli which were grown with and without $\mathrm{NaCl}$ stress analyzed using GC-MS method. The analysis carried out using the instrument method - C:/Xcaliber/RCE KKD/DRUGS//METHOD/NAT. PRODUCTS. Meth - from Department of Applied Chemistry, KFRI (Kerala Forest Research Institute), Peechi, Trissur, Kerala, India.

\section{RESULTS AND DISCUSSION}

\section{Callus Induction}

The valuable medicinal plant, A. precatorius, is using to treat different types of human diseases due to the presence of different secondary metabolites. While the hard seed coat and difficulty in vegetative propagation is the major problem to produce the healthy seedlings in bulk. To overcome the issue, the tissue culture technique is highly useful nowadays. The present study reveals the callus regeneration from inter nodal explant within 14 days when cultured on MS medium fortified with BAP $0.5 \mathrm{mg} / \mathrm{L}+$ Kinetin $1 \mathrm{mg} / \mathrm{L}$ and BAP $1 \mathrm{mg} / \mathrm{L}+$ IBA $0.5 \mathrm{mg} / \mathrm{L}$. The remaining media induced callus regeneration on explants within 21 days (Table 1). The specific concentration and combination of BAP, IBA and Kinetin is the basic reason for callogenesis. Each plant needs an optimum concentration of cytokinine and/or auxin for

Table 1: Fresh weight (gm), dry weight (gm) and biomass (gm) of calli that grown on different media. The values are mean \pm $\mathrm{SE}, \mathrm{N}=5$, significant at $5 \%$ level using single factor ANOVA.

\begin{tabular}{|c|c|c|}
\hline Compositions of media & $\begin{array}{l}\text { Fresh weight Dry weight } \\
(\mathrm{gm})+\mathrm{SE}(\mathrm{gm})+\mathrm{SE}\end{array}$ & $\begin{array}{l}\text { Callus biomass } \\
\text { (gm) }+ \text { SE }\end{array}$ \\
\hline $\mathrm{MS}+\mathrm{BAP} 0.5 \mathrm{mg} / \mathrm{L}+\mathrm{IBA} 0.5 \mathrm{mg} / \mathrm{L}$ & $1.84 \pm 0.010 .75 \pm 0.02$ & $1.43 \pm 0.02$ \\
\hline $\mathrm{MS}+\mathrm{BAP} 1 \mathrm{mg} / \mathrm{L}+\mathrm{IBA} \mathrm{lmg} / \mathrm{L}$ & $1.72 \pm 0.03 \quad 0.78 \pm 0.01$ & $1.15 \pm 0.01$ \\
\hline $\mathrm{MS}+\mathrm{BAP} 0.5 \mathrm{mg} / \mathrm{I}+\mathrm{IBA} \mathrm{mg} / \mathrm{L}$ & $1.88 \pm 0.010 .73 \pm 0.01$ & $1.57 \pm 0.03$ \\
\hline $\mathrm{MS}+\mathrm{BAP} 1 \mathrm{mg} / \mathrm{L}+\mathrm{IBA} 0.5 \mathrm{mg} / \mathrm{L}$ & $2.05 \pm 0.02 \quad 0.80 \pm 0.03$ & $1.56 \pm 0.01$ \\
\hline $\mathrm{MS}+\mathrm{BAP} 0.5 \mathrm{mg} / \mathrm{L}+$ Kinetin $0.5 \mathrm{mg} / \mathrm{L}$ & $-1.76 \pm 0.030 .80 \pm 0.006$ & $1.20 \pm 0.02$ \\
\hline MS +BAPlmg/L+Kinetinlmg/L & $1.80 \pm 0.040 .79 \pm 0.01$ & $1.28 \pm 0.01$ \\
\hline $\mathrm{MS}+\mathrm{BAP} 0.5 \mathrm{mg} / \mathrm{L}+$ Kinetin $1 \mathrm{mg} / \mathrm{L}$ & $2.08 \pm 0.01 \quad 0.72 \pm 0.02$ & $1.89 \pm 0.04$ \\
\hline MS + BAPlmg/L+Kinetin0.5mg/L & $-1.96 \pm 0.020 .72 \pm 0.01$ & $1.72 \pm 0.01$ \\
\hline $\begin{array}{l}\mathrm{MS}+\mathrm{BAP} 0.5 \mathrm{mg} / \mathrm{L}+\text { Kinetinlmg/ } \\
\mathrm{L}+\mathrm{NaCl} 20 \mathrm{mM}\end{array}$ & $1.24 \pm 0.02 \quad 0.59 \pm 0.02$ & $1.10 \pm 0.03$ \\
\hline $\begin{array}{l}\mathrm{MS}+\mathrm{BAP} 0.5 \mathrm{mg} / \mathrm{L}+\text { Kinetinlmg/ } \\
\mathrm{L}+\mathrm{NaCl} 40 \mathrm{mM}\end{array}$ & $1.68 \pm 0.04 \quad 0.65 \pm 0.01$ & $1.58 \pm 0.02$ \\
\hline $\begin{array}{l}\mathrm{MS}+\mathrm{BAP} 0.5 \mathrm{mg} / \mathrm{L}+\text { Kinetinlmg/ } \\
\mathrm{L}+\mathrm{NaCl} 60 \mathrm{mM}\end{array}$ & $1.06 \pm 0.050 .46 \pm 0.002$ & $1.30 \pm 0.01$ \\
\hline $\begin{array}{l}\mathrm{MS}+\mathrm{BAP} 0.5 \mathrm{mg} / \mathrm{L}+\text { Kinetinlmg/ } \\
\mathrm{L}+\mathrm{NaCl} 80 \mathrm{mM}\end{array}$ & $0.81 \pm 0.010 .45 \pm 0.003$ & $0.80 \pm 0.005$ \\
\hline $\begin{array}{l}\mathrm{MS}+\mathrm{BAP} 0.5 \mathrm{mg} / \mathrm{L}+\text { Kinetinlmg/ } \\
\mathrm{L}+\mathrm{NaCl} 100 \mathrm{mM}\end{array}$ & $0.47 \pm 0.040 .29 \pm 0.001$ & $0.62 \pm 0.01$ \\
\hline
\end{tabular}


callogenesis from the explants. In the investigation of Biswas et al. (2007), the callus developed from the cut surface of nodal explants that cultured on MS medium fortified with $5.0 \mathrm{mg} / \mathrm{L} \mathrm{BAP}$ and $0.5 \mathrm{mg} / \mathrm{L} \mathrm{NAA}$. While the callus induction from nodal, intermodal and tendril explants of A. precatorius was successfully done by Ramar et al. (2018).

In the study, the callus was white in colour, compact and nonembryogenic initially; but gradually it turned to green (Figure 1). In contrast, the formation of yellowish and compact callus from the nodal segments of $A$. precatorius on MS + 2,4-D $1 \mathrm{mg} / \mathrm{L}$ + NAA $1 \mathrm{mg} / \mathrm{L}$ reported by Hassan et al. (2009) in which the different concentration of auxins induced the callus formation. The callus is the mass of undifferentiated tissue that in turn regenerates the in vitro plantlets. The nature of the callus, compact or friable/embryogenic or non-embryogenic, depends to the plant species. Within 63 days, the callus grown on MS medium supplemented with BAP $0.5 \mathrm{mg} / \mathrm{L}+$ Kinetin $1 \mathrm{mg} / \mathrm{L}$ and BAP $1 \mathrm{mg} / \mathrm{L}+\mathrm{IBA} 0.5 \mathrm{mg} / \mathrm{L}$ showed maximum rate of fresh weight (FW) and dry weight (DW). It proves the higher callus induction and proliferation potential in presence of specific media composition. As the age of calli increased, the colour changed gradually from green to yellowish-brown. The browning of calli may be due to nutrient depletion or accumulation of phenolic compounds in cells. Sometimes, these cells get ruptured by higher plasmolysis that causes releasing of phenolics into the media (Jones and Saxena, 2013).

\section{In vitro Salt Stress}

In vitro production of salt tolerant lines has a significant role in agriculture and pharmacognosy. The regenerated plants can overcome the salinity stress by the presence of an internal genetic mechanism that controls the salt tolerant plant metabolism (Tuteja, 2007). Typically, the salt stress declines the callus induction and regeneration frequency in salt sensitive plants. But, some plants can resist the negative influence of in vitro salinity and regenerate the salt tolerant lines (Basu et al., 2002).

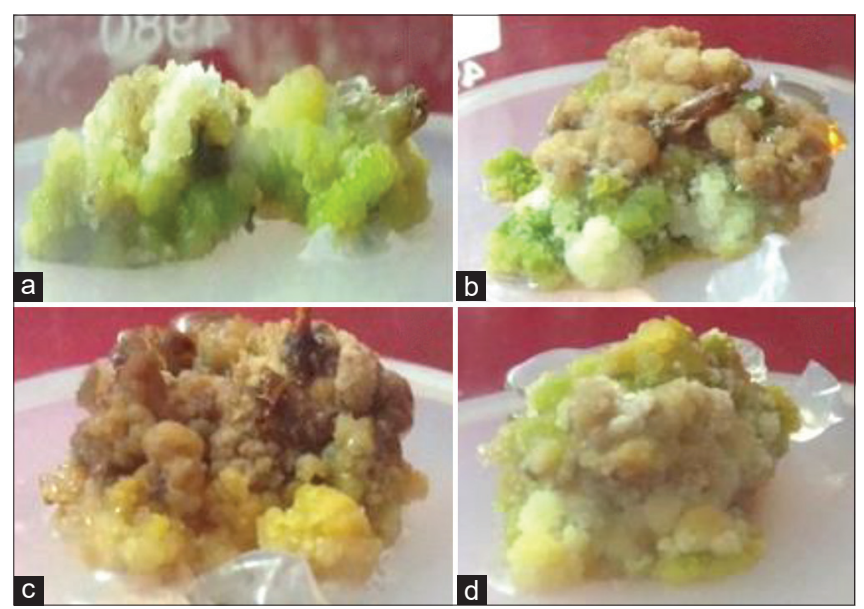

Figure 1: Callus induction from the internodes of $A$. precatorius on different culture media; a. MS + BAP $0.5 \mathrm{mg} / \mathrm{L}+$ Kinetin $1 \mathrm{mg} / \mathrm{L}, \mathrm{b} . \mathrm{MS}+$ BAP $1 \mathrm{mg} / \mathrm{L}$ + IBA $0.5 \mathrm{mg} / \mathrm{L}, \mathrm{c} . \mathrm{MS}+\mathrm{BAP} 1 \mathrm{mg} / \mathrm{L}+$ Kinetin $0.5 \mathrm{mg} / \mathrm{L}$ and d. MS + BAP $0.5 \mathrm{mg} / \mathrm{L}+\mathrm{IBA} 1 \mathrm{mg} / \mathrm{L}$
In the study, the salinity brings about the morphological and biochemical changes in calli that were sub-cultured on MS medium supplemented with BAP $0.5 \mathrm{mg} / \mathrm{L}$, Kinetin $1 \mathrm{mg} / \mathrm{L}$ and different concentrations of $\mathrm{NaCl}(20,40,60,80$ and $100 \mathrm{mM})$. The proliferation, fresh weight, dry weight and biomass of calli were enhanced when the calli cultured on MS medium fortified with $\mathrm{NaCl}$ concentration up to $40 \mathrm{mM}$ (Table 1). Then the calli proliferation gradually decreased when the concentration of $\mathrm{NaCl}$ increased from $40 \mathrm{mM}$ to $100 \mathrm{mM}$. Now, many of the recent studies have focused on the regeneration of salt tolerant rice varieties viz., Navara, IR-64, SR-26B, Chini Kanai, BRRI Dhan 38 etc. through the tissue culture techniques in which the plantlets urged the genetic potential to survive under salt stress condition (Basu et al., 2002; Priya et al., 2011; Zinnah et al., 2013). Furthermore, the reduction of proliferation frequency and fresh weight of in vitro calli under salinity stress observed in different medicinal plants (Patade et al., 2008). The influence of salinity leads to the colour variations in calli. The calli of A. precatorius grown on medium supplemented with $\mathrm{NaCl}$ upto $40 \mathrm{mM}$ concentration showed yellow colour with compact and non-embryogenic consistency. While the yellowish callus changed to brown colour when the concentration of $\mathrm{NaCl}$ increased from $60 \mathrm{mM}$ to $100 \mathrm{mM}$ (Figure 2).

Most of the studies related to salinity stress encompass the darkening of calli. It may due to the unavailability of water for proper metabolic activities. Meanwhile, the higher concentration of $\mathrm{NaCl}$ has an influence on the secondary metabolism that results in the amelioration of medicinally important metabolite production compared to the calli cultured without salt stress (Hasegawa et al., 2000; Zhu, 2001). The presence of these metabolites also causes the browning of calli. To avoid the negative impact of soil salinity on agriculture, the regeneration of salt tolerant plantlets is significant which can be done by the application of appropriate ratio of auxins and cytokinins in the culture medium of salt tolerant calli.

\section{Secondary Metabolite Production}

Application of salt stress in in vitro culture is a better method to produce valuable secondary metabolites with medicinal value. In the pharmaceutical industry, there are different methods to isolate and detect secondary metabolites from plant extracts. GC-MS analysis is one of the advanced techniques to identify different organic metabolites from the extracts of medicinal plants (Safaei-Ghomi et al., 2009). In the study, the secondary compounds of calli which cultured on medium with and without $\mathrm{NaCl}$ stress were detected using the GC-MS method. The number of detected compounds was higher in callus grown under $\mathrm{NaCl}$ stress compared to the calli cultured without $\mathrm{NaCl}$. The enhancement of secondary metabolite production under salt stress is detected in many of the in vitro plant cultures (Jaleel et al., 2008; Rishla et al., 2017). In Carthamus tinctorius L., the supplementation of $\mathrm{NaCl}$ below $100 \mathrm{mM}$ concentration in Hoagland solution improved the production of medicinal flavonoids (Gengmao et al., 2015). Presently, seventeen compounds were analyzed from the salt tolerant callus of $A$. precatorius; of which the 
compound, 5-ethyl-1-nonene showed the lowest retention time (RT), 4.24. While, the highest RT exhibited by 1,1,1-trifluoroheptadecen-2-one, 33.19. Retention time indicates the time taken by the organic compounds/solutes to pass through the chromatography column that influenced by many factors including column length, column degradation, gas flow rate etc. (Ezhilan and Neelamegam, 2012). Among the compounds, stigmasterol showed the highest area percentage (33.94\%) and the lowest area percentage by ethyl palmitate $(0.43 \%)$ Table 2, Figure $3 \& 4)$. Interestingly, thirteen new

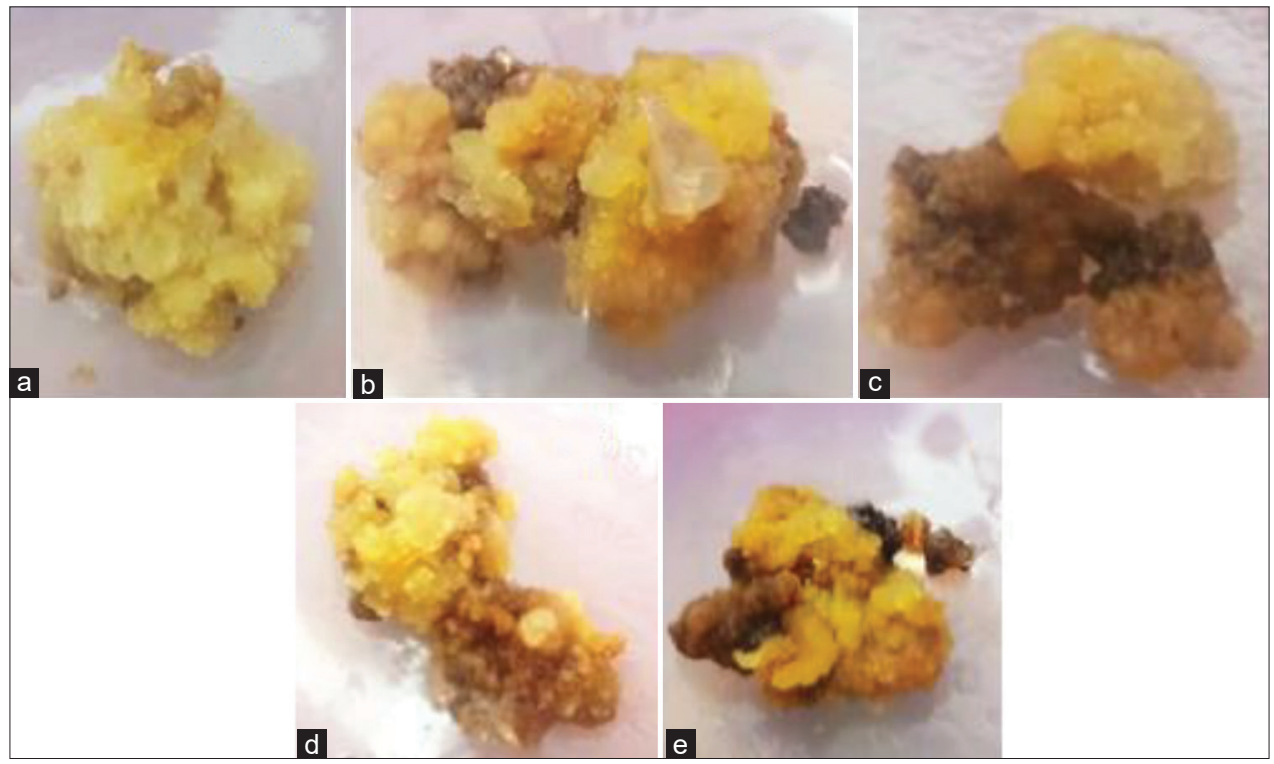

Figure 2: Callus proliferation of $A$. precatorius on MS + BAP $0.5 \mathrm{mg} / \mathrm{L}+$ Kinetin $1 \mathrm{mg} / \mathrm{L}$ supplemented with different concentrations of $\mathrm{NaCl}$ (20 (a), 40 (b), 60 (c), 80 (d) and 100 (e) $\mathrm{mM}$ )

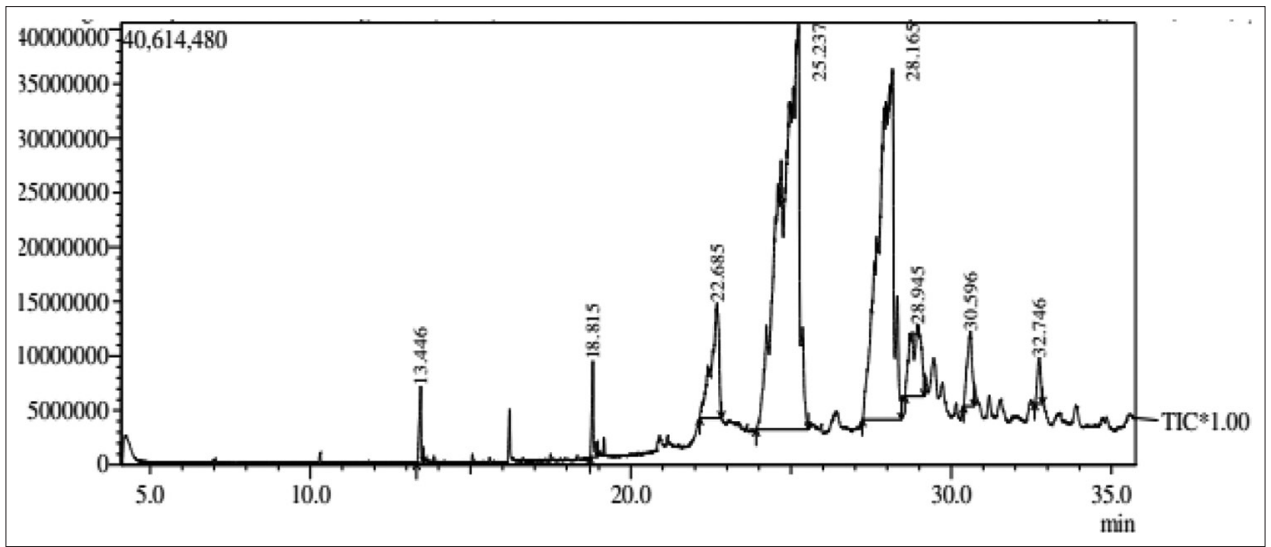

Figure 3: GC-MS chromatogram of compounds observed in callus grown without $\mathrm{NaCl}$ stress

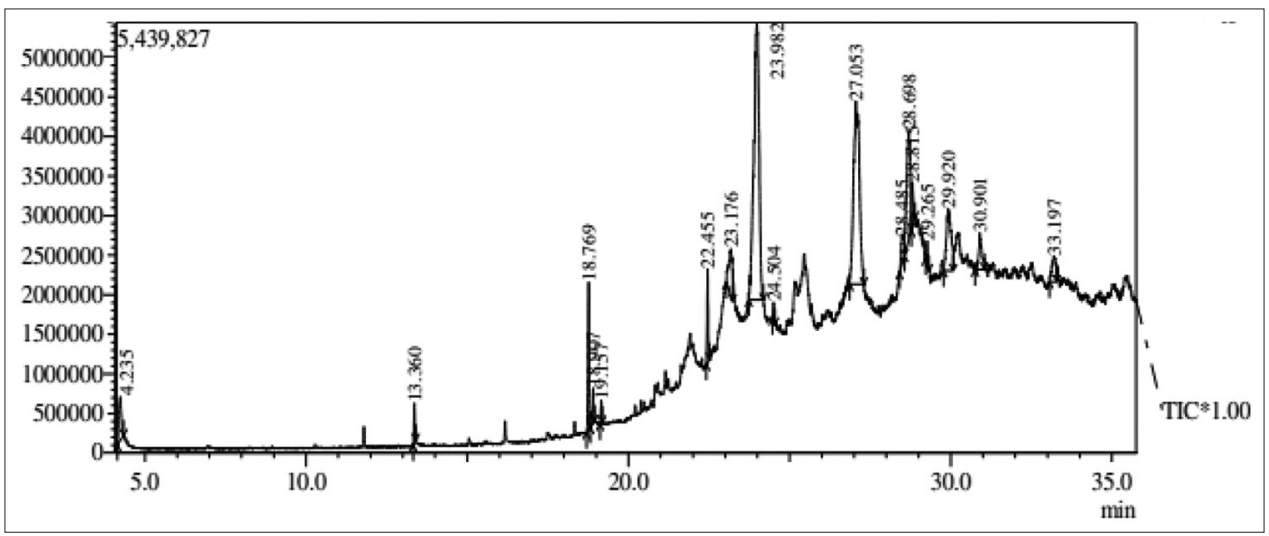

Figure 4: GC-MS chromatogram of compounds observed in callus grown with $\mathrm{NaCl}$ stress 
Table 2: Compounds analyzed from callus grown with and without $\mathrm{NaCl}$ stress using GC-MS.

\begin{tabular}{|c|c|c|c|c|}
\hline \multicolumn{4}{|c|}{ SI. No. Retention TimeArea \%Compounds } & \multirow[t]{2}{*}{ Nature of callus } \\
\hline 1 & 13.45 & 0.89 & Dodecanoic acid & \\
\hline 2 & 18.82 & 0.98 & Pentadecanoic acid & \multirow{8}{*}{$\begin{array}{l}\text { Callus grown } \\
\text { without } \mathrm{NaCl}\end{array}$} \\
\hline 3 & 22.69 & 5.79 & Campesterol & \\
\hline 4 & 25.24 & 49.18 & Stigmasterol & \\
\hline 5 & 28.17 & 34.85 & beta-Sitosterol & \\
\hline 6 & 28.95 & 4.93 & beta-Amyrin & \\
\hline 7 & 30.60 & 2.39 & Spinasterone & \\
\hline 8 & 32.75 & 0.99 & Sitostenone & \\
\hline 1 & 4.24 & 2.72 & 5-Ethyl-1-nonene & \\
\hline 2 & 13.36 & 0.79 & Dodecanoic acid & \multirow{16}{*}{$\begin{array}{l}\text { Callus grown } \\
\text { with } \mathrm{NaCl}\end{array}$} \\
\hline 3 & 18.77 & 3.90 & Pentadecanoic acid & \\
\hline 4 & 18.91 & 1.14 & Dibutyl phthalate & \\
\hline 5 & 19.16 & 0.43 & Ethyl palmitate & \\
\hline 6 & 22.46 & 1.92 & $\begin{array}{l}\text { trans-Pinosylvin dimethyl } \\
\text { ether }\end{array}$ & \\
\hline 7 & 23.18 & 3.83 & Stigmasterol methyl ether & \\
\hline 8 & 23.98 & 33.94 & Stigmasterol & \\
\hline 9 & 24.50 & 0.46 & Pinostrobin chalcone & \\
\hline 10 & 27.05 & 24.81 & Gamma-Sitosterol & \\
\hline 11 & 28.49 & 1.76 & Beta-Amyrin & \\
\hline 12 & 28.70 & 10.00 & $\begin{array}{l}5 \text { Alpha-Stigmastane-3,6- } \\
\text { dione }\end{array}$ & \\
\hline 13 & 28.82 & 1.77 & Illudol & \\
\hline 14 & 29.27 & 0.69 & Squalene & \\
\hline 15 & 29.92 & 6.82 & Citrost-7-en-3-ol & \\
\hline 16 & 30.90 & 2.52 & Beta-Saccharostenone & \\
\hline 17 & 33.19 & 2.49 & $\begin{array}{l}\text { 1,1,1-Trifluoroheptadecen- } \\
\text { 2-one }\end{array}$ & \\
\hline
\end{tabular}

compounds were detected from the salt tolerant callus that was not observed in the callus grown without $\mathrm{NaCl}$ stress. The type and concentration of secondary metabolites produced by an in vitro plant is determined by its genotype, physiology, developmental stage and environmental factors during growth (Isah, 2019). Moreover, the different environmental factors viz. temperature, light intensity, the supply of water and minerals etc., have a considerable role in secondary metabolite production (Ramakrishna and Ravishankar, 2011). Though, eight different secondary metabolites were analyzed in calli cultured on medium without $\mathrm{NaCl}$ to which dodecanoic acid showed the lesser RT, 13.45 and sitostenone exhibited higher value. In the analysis, stigmasterol and dodecanoic acid were with higher and lower area percentage respectively (Table 2 ). As reported by many researchers, the detected metabolites in calli of A. precatorius show antimicrobial, antioxidant and anti-inflammatory activities (Agboke, 2015; Parasuraman et al., 2016; Patel et al., 2016). Remarkably, the present study will be very much helpful in pharmacology to produce medicinally significant compounds in future.

\section{CONCLUSION}

The white seeded A. precatorius is an important source of organic compounds with therapeutic effects. In vitro culture plays as the best method to multiply the species. The MS medium supplemented with BAP $0.5 \mathrm{mg} / \mathrm{L}+$ Kinetin $1 \mathrm{mg} / \mathrm{L}$ and BAP $1 \mathrm{mg} / \mathrm{L}+\mathrm{IBA} 0.5 \mathrm{mg} / \mathrm{L}$ showed better callus induction within a short period. These green compact non-embryogenic calli were with highest fresh weight, dry weight and biomass. The presence of $\mathrm{NaCl}$ negatively influenced on callus proliferation of which calli cultured with $40 \mathrm{mM} \mathrm{NaCl}$ exhibited a greater degree of callus biomass. This salt tolerant calli is the source of 17 different medicinally important metabolic compounds that may be a new breakthrough in the field of drug discovery.

\section{ACKNOWLEDGEMENT}

The authors are very much thankful to the Principal, Korambayil Ahammed Haji Memorial Unity Women's College, Manjeri, Kerala, India for providing the laboratory facilities to complete the work.

\section{REFERENCES}

Agboke, A. A. (2015). Antimicrobial activity of ethanol extract and fractions of Moringa oleifera Lam. root bark on clinical isolates of methicillin resistant Staphylococcus aureus. Methods, 8, 17-19.

Basu, S., Gangopadhyay, G., and Mukherjee, B. B. (2002). Salt tolerance in rice in vitro: Implication of accumulation of $\mathrm{Na}^{+}, \mathrm{K}^{+}$and proline. Plant Cell, Tissue and Organ Culture, 69(1), 55-64. https:// doi.org/10.1023/A:1015028919620

Biswas, A., Roy, M., Miah, M. B., and Bhadra, S. K. (2007). In vitro propagation of Abrus precatorius L. - a rare medicinal plant of Chittagong hill tracts. Plant Tissue Culture and Biotechnology, 17(1), 59-64. https://doi.org/10.3329/ptcb.v17i1.1121

Ezhilan, B. P., and Neelamegam, R. (2012). GC-MS analysis of phytocomponents in the ethanol extract of Polygonum chinense L. Pharmacognosy Research, 4(1), 11-14. https://doi. org/10.4103/0974-8490.91028

Gengmao, Z., Yu, H., Xing, S., Shihui, L., Quanmei, S., and Changhai, W. (2015). Salinity stress increases secondary metabolites and enzyme activity in safflower. Industrial Crops and Products, 64, 175-181. https://doi.org/10.1016/j.indcrop.2014.10.058

Hasegawa, P. M., Bressan, R. A., Zhu, J. K., and Bohnert, H. J. (2000). Plant cellular and molecular responses to high salinity. Annual Review of Plant Biology, 51(1), 463-499. https://doi.org/10.1146/annurev. arplant.51.1.463

Hassan, M. M., Azam, F. S., Chowdhury, M. H., and Rahmatullah, M. (2009). Callus induction of Abrus precatorius: screening of phytohormones. American-Eurasian Journal of Sustainable Agriculture, 512-519.

Ibrahim, M. H., Shibli, N. I., Izad, A. A., and Zain, N. A. M. (2018). Growth, chlorophyll fluorescence, leaf gas exchange and phytochemicals of Centella asiatica exposed to salinity stress. Annual Research and Review in Biology, 27(2), 1-13. https://doi.org/10.9734/ ARRB/2018/41014

Isah T. (2019). Stress and defense responses in plant secondary metabolites production. Biological Research, 52(1), 39. https://doi. org/10.1186/s40659-019-0246-3

Jaleel, C. A., Sankar, B., Sridharan, R., and Panneerselvam, R. (2008). Soil salinity alters growth, chlorophyll content, and secondary metabolite accumulation in Catharanthus roseus. Turkish Journal of Biology, 32(2), 79-83.

Jones, A. M., and Saxena, P. K. (2013). Inhibition of phenylpropanoid biosynthesis in Artemisia annua L.: a novel approach to reduce oxidative browning in plant tissue culture. PloS one, 8(10), e76802. https://doi.org/10.1371/journal.pone.0076802

Joshi, S. G., and Joshi, S. G. (2000). Medicinal plants. Oxford and IBH publishing.

Lewis, G., Schrire, B., Mackinder, B., and Lock, M. (2005). Tribe Abreae. Legumes of the world: Royal Botanic Gardens, Kew, 389-392.

Loberant, B., and Altman, A. (2009). Micropropagation of plants. Encyclopedia of Industrial Biotechnology: Bioprocess, Bioseparation, and Cell Technology, 1-17.

Marton, L., and Czako, M. U. S. (2011). Washington, DC: U.S. Patent and Trademark Office. Patent No. 7, 863, 046.

Parasuraman, S., Ren, L. Y., Chuon, B. L. C., Yee, S. W. K., Qi, T. S., Ching, J. Y. S., and Raj, P. V. (2016). Phytochemical, antimicrobial and mast cell stabilizing activity of ethanolic extract of Solanum trilobatum Linn. 
leaves. Malaysian Journal of Microbiology, 12(5), 359-364.

Patade, V. Y., Suprasanna, P., and Bapat, V. A. (2008). Effects of salt stress in relation to osmotic adjustment on sugarcane (Saccharum officinarum L.) callus cultures. Plant Growth Regulation, 55(3), 169. https://doi. org/10.1007/s10725-008-9270-y

Patel, N. K., Jaiswal, G., and Bhutani, K. K. (2016). A review on biological sources, chemistry and pharmacological activities of pinostrobin. Natural Product Research, 30(18), 2017-2027. https:// doi.org/10.1080/14786419.2015.1107556

Patra, J. K., and Mohanta, Y. K. (2014). Antimicrobial compounds from mangrove plants: A pharmaceutical prospective. Chinese Journal of Integrative Medicine, 20(4), 311-320. https://doi.org/10.1007/ s11655-014-1747-0

Priya, A. M., Pandian, S. K., and Ramesh, M. (2011). Effect of $\mathrm{NaCl}$ on in vitro plant regeneration from embryogenic callus cultures of cv IR 64 indica rice (Oryza sativa L.). African Journal of Biotechnology, 10(36), 6947-6953.

Ramakrishna, A., and Ravishankar, G. A. (2011). Influence of abiotic stress signals on secondary metabolites in plants. Plant Signaling and Behavior, 6(11), 1720-1731. https://doi.org/10.4161/psb.6.11.17613

Ramar, K., Dhinesh, V., Kannanur, T., and Kanimozhi, A. (2018). In vitro callus induction studies on Abrus precatorius L., A medicinal plant. International Journal of Advance Research, Ideas and Innovations in Technology, 4(2), 1496-1500.

Rishla, K., Sithara, A., and Deepa, P. (2017). Effect of $\mathrm{NaCl}$ stress on callus induction in Centella asiatica (L.) Urban. European Journal of Biomedical and Pharmaceutical Sciences, 1, 1-50.

Roy, S., Acharya, R., Mandal, N. C., Barman, S., Ghosh, R., and Roy, R. (2012). A comparative antibacterial evaluation of raw and processed Guñjā (Abrus precatorius Linn.) seeds. Ancient Science of Life, 32(1),
20-23. https://doi.org/10.4103/0257-7941.113794

Safaei-Ghomi, J., Ebrahimabadi, A. H., Djafari-Bidgoli, Z., and Batooli, H. (2009). GC/MS analysis and in vitro antioxidant activity of essential oil and methanol extracts of Thymus caramanicus Jalas and its main constituent carvacrol. Food Chemistry, 115(4), 1524-1528. https://doi. org/10.1016/.foodchem.2009.01.051

Sahari, M. A., Mehrafarin, A., and Naghdi, B. H. (2016). Changes of trigonelline, nicotinic acid and proline content in early growth stages of Trigonella foenum-graecum L. under Saline condition. Journal of Medicinal Plants, 15(57), 47-55.

Sermakkani, M., and Thangapandian, V. (2012). GC-MS analysis of Cassia italica leaf methanol extract. Asian Journal of Pharmaceutical and Clinical Research, 5(2), 90-94.

Swanepoel, W., and Kolberg, H. (2011). Abrus kaokoensis (LeguminosaePapilionoideae-Abreae), a new species from Namibia. South African Journal of Botany, 77(3), 613-617. https://doi.org/10.1016/j. sajb.2010.12.005

Tuteja, N. (2007). Mechanisms of high salinity tolerance in plants. In Methods in enzymology (pp. 428, 419-438), Academic Press.

Yang, L., Wen, K. S., Ruan, X., Zhao, Y. X., Wei, F., and Wang, Q. (2018). Response of Plant Secondary Metabolites to Environmental Factors. Molecules, 23(4), 762. https://doi.org/10.3390/ molecules23040762

Zhu J. K. (2001). Cell signaling under salt, water and cold stresses. Current Opinion in Plant Biology, 4(5), 401-406. https://doi.org/10.1016/ s1369-5266(00)00192-8

Zinnah, K. M. A., Zobayer, N. S., Sikdar, S. U., Liza, L. N., Chowdhury, M. A. N., and Ashrafuzzaman, M. (2013). In vitro regeneration and screening for salt tolerance in rice (Oryza sativa L.). International Research Journal of Biological Sciences, 2(11), 29-36. 